\title{
Combustion Kinetics of Shankodi-Jangwa Coal
}

\author{
Bemgba Bevan Nyakuma, ${ }^{1 *}$ Aliyu Jauro, ${ }^{2}$ Olagoke Oladokun, ${ }^{1}$ \\ Tuan Amran Tuan Abdullah ${ }^{1}$ and Habibu Uthman ${ }^{3}$ \\ ${ }^{1}$ Centre for Hydrogen Energy Institute of Future Energy, \\ Chemical Engineering Department, Universiti Teknologi Malaysia, \\ 81110 Skudai, Johor, Malaysia \\ ${ }^{2}$ National Centre for Petroleum Research and Development, \\ Abubakar Tafawa Balewa University, Bauchi, Nigeria \\ ${ }^{3}$ Centre for Hydrogen Energy, Institute of Future Energy, \\ Chemical Engineering Department, Universiti Teknologi Malaysia, \\ International Campus, 54100 Kuala Lumpur, Malaysia \\ *Corresponding author: bbnyax1@gmail.com
}

Published online: 25 November 2016

To cite this article: Nyakuma, B. et al. (2016). Combustion kinetics of Shankodi-Jangwa coal. J. Phys. Sci., 27(3), 1-12, http://dx.doi.org/10.21315/jps2016.27.3.1

To link to this article: http://dx.doi.org/10.21315/jps2016.27.3.1

\begin{abstract}
The lack of comprehensive data on the fuel properties of newly discovered coal deposits in Nigeria has hampered the prospective utilisation for power generation. Consequently, this study is aimed at characterising the physicochemical and thermokinetic properties of Shankodi-Jangwa (SKJ) coal recently discovered in Nassarawa state, Nigeria. The results indicate that SKJ comprises $40.50 \%$ fixed carbon, $43.34 \%$ volatile matter, and $2.36 \%$ sulphur with a higher heating value (HHV) of 27.37 $M J \mathrm{~kg}^{-1}$. Based on this HHV, SKJ was classified as high-volatile B bituminous coal. Thermal analysis of SKJ under oxidative thermogravimetry (TG) at multiple heating rates revealed that $S K J$ is highly reactive and thermally degradable below $1000^{\circ} \mathrm{C}$. Kinetic analysis using the Flynn-Wall-Ozawa model for conversions $\alpha=0.05-0.90$ revealed the activation energy to range from $E_{a}=113-259 \mathrm{~kJ} \mathrm{~mol}^{-1}$, with the frequency factor ranging from $A=2.9 \times 10^{13}-1.5 \times 10^{23} \mathrm{~min}^{-1}$ and a range in $R^{2}=0.8536-0.9997$; the average values of these ranges are $E_{a}=184 \mathrm{~kJ} \mathrm{~mol}^{-1}, A=9.2 \times 10^{23} \mathrm{~min}^{-1}$ and $R^{2}=0.9420$, respectively. The study highlighted fuel property data vital for modelling and designing future SKJ coal power generation.
\end{abstract}

Keywords: Combustion, thermal, kinetics, Shankodi-Jangwa, coal, Nigeria 


\section{INTRODUCTION}

Coal utilisation for electricity generation currently accounts for $40 \%$ of global power consumption. According to the International Energy Agency (IEA), the global annual demand for coal currently exceeds $2.6 \%$ of global energy usage and will account for $14.5 \%$ of the global energy mix by 2035 . This will be evident in developing countries with large coal reserves beset by socioeconomic and energy poverty. ${ }^{1}$ Since energy is crucial to poverty alleviation, developing countries require access to cheap and sustained energy supply to spur socioeconomic growth and sustainable development.

Nigeria has one of the largest coal reserves in Africa, estimated at 2.75 billion metric tonnes and containing large unexploited deposits. ${ }^{2}$ The recent discoveries of large coal deposits in Garin Maiganga (GMG), Afuze (AFZ) and ShankodiJangwa (SKJ) have reignited the prospects of coal power generation in Nigeria. ${ }^{3,4}$ However, the lack of comprehensive scientific data on coal properties and other sociotechnical factors have hampered utilisation. Furthermore, current research on Nigerian coals is mainly focused on rheological, ${ }^{3,5}$ petrographic, ${ }^{6-8}$ mineralogical, ${ }^{9-10}$ geological and geochemical ${ }^{11-13}$ properties, although some research groups have investigated coal conversion $^{14,15}$ and hydrocarbon potential. $^{16,17}$

Consequently, there is inadequate empirical data on the physicochemical and thermokinetic properties of Nigerian coals vital for classification (ranking) and assessing their suitability for utilisation. Because the vast majority of coal-fired power plants utilise pulverised coal combustion (PCC) technologies for power generation, it is imperative to investigate the combustion kinetics of Nigerian coals. Therefore, this study is aimed at investigating the physicochemical properties of SKJ coal in addition to its thermokinetic properties under oxidative (combustion) conditions. Thermal degradation kinetics will be examined based on the Flynn-Wall-Ozawa model.

\section{EXPERIMENTAL}

\subsection{Materials and Methods}

The coal sample was acquired from SKJ village in Nassarawa state, Nigeria. The sample was pulverised and sifted to obtain particles below $250 \mu \mathrm{m}$. Next, the pulverised coal was characterised by ultimate, proximate and bomb calorimetric analyses. Thermal decomposition behaviour was investigated in the Perkin Elmer TGA 4000 Thermogravimetric (TG) analyser by heating $8-10 \mathrm{mg}$ of sample in an 
alumina crucible from $35^{\circ} \mathrm{C}-1000^{\circ} \mathrm{C}$ at $\beta=10,20,30^{\circ} \mathrm{C} \mathrm{min}^{-1}$ under an ultrapure oxygen $\left(\mathrm{O}_{2}\right)$ purge gas flow rate of $20 \mathrm{ml} \mathrm{min}^{-1}$. Subsequently, the resulting thermograms were analysed using the Pyris 6 TGA software to determine oxidative temperature profiles of SKJ. Next, the parameters of activation energy, $E_{a}$, and frequency factor, $A$, were deduced using the Flynn-Wall-Ozawa kinetic model for conversion $\alpha=0.05$ to 0.90 .

\subsection{Kinetic Model Theory}

The thermal decomposition of SKJ coal under combustion (oxidative) conditions can be represented by the general equation:

$$
\frac{d \alpha}{d t}=k(T) f(\alpha)
$$

where $\alpha$ represents the degree of conversion, $t$ represents time, $k(\mathrm{~T})$ is the rate constant dependent on temperature, $T$ is absolute temperature, and $f(\alpha)$ is the function of the reaction mechanism occurring during thermal degradation of the material. Consequently, the degree of conversion, $\alpha$, can be expressed as: $:^{18,19}$

$$
\alpha=\frac{m_{i}-m_{t}}{m_{i}-m_{\infty}}
$$

where $m_{i}$ represents the initial sample mass, $m_{t}$ is the sample mass at time $t$, and $m_{\infty}$ is the final sample mass at the end of the reaction. According to the Arrhenius equation, the temperature dependent rate constant, $k(\mathrm{~T})$, can be defined as:

$$
k(T)=A \exp \left(\frac{E_{a}}{R T}\right)
$$

where $A$ is the frequency factor $\left(\mathrm{min}^{-1}\right), E_{a}$ is activation energy $\left(\mathrm{kJ} \mathrm{mol}{ }^{-1}\right), R$ is the universal gas constant $\left(\mathrm{J} \mathrm{mol}^{-1} \mathrm{~K}^{-1}\right)$ and $T$ is absolute temperature $(\mathrm{K})$, respectively. Consequently, the rate of sample degradation and the effect of the rate-dependent constant on the mechanism of reaction can be obtained by substituting Equation 3 into Equation 1 as given by:

$$
\frac{d \alpha}{d t}=A \exp \left(\frac{E_{a}}{R T}\right) f(\alpha)
$$


By considering and introducing the effect of the heating rate, $\beta$, defined as:

$$
\beta=\frac{d T}{d t}
$$

The thermal degradation of SKJ coal sample can be represented by the equation:

$$
\frac{d \alpha}{d t}=\frac{A}{\beta} \exp \left(-\frac{E_{a}}{R T}\right) f(\alpha)
$$

After separation of the variables, Equation 6 can be expressed as:

$$
\frac{d \alpha}{f(\alpha)}=\frac{A}{\beta} \exp \left(-\frac{E_{a}}{R T}\right) d t
$$

By integrating Equation 7, the conversion function, $g(\alpha)$, which describes the thermokinetic decomposition of the SKJ coal at a specific heating rate, can be expressed as:

$$
g(\alpha)=\int_{0}^{\alpha} \frac{d \alpha}{f(\alpha)}=\frac{A}{\beta} \int_{T_{0}}^{T} \exp \left(-\frac{E_{a}}{R T}\right) d t
$$

This is the fundamental equation for analysing the parameters of decomposition kinetics; activation energy, $E_{a}$, and the frequency factor of materials, $A$. By introducing the Doyle's approximation, ${ }^{20}$ the solution to Equation 8 can be deduced, thereby presenting the basis for the isoconversional Flynn-Wall-Ozawa kinetic model given by:

$$
\ln (\beta)=\ln \left(\frac{A E_{a}}{R g_{\alpha}}\right)-5.331-1.052\left(\frac{E_{a}}{R T}\right)
$$

Hence, the kinetic parameters $E_{a}$ and $A$ can be deduced by plotting $\operatorname{In}(\beta)$ against $(1 / \mathrm{T})$. The $E_{a}$ can be calculated from the slope $-1.052 E_{a} / R$ (where $R=8.314 \mathrm{~J}$ $\mathrm{mol}^{-1} \mathrm{~K}^{-1}$ ), while $A$ can be calculated from the intercept $\operatorname{In}\left[A R / E_{a}\right]$. 


\section{RESULTS AND DISCUSSION}

\subsection{Physicochemical Fuel Properties}

Table 1 presents the physicochemical properties of SKJ coal in dry basis (db). For comparison, the results of this study have been compared with values for SKJ coal reported by Ryemshak and Jauro. ${ }^{3}$

Table 1: Physicochemical fuel properties of SKJ coal in $\mathrm{wt} \%$ dry basis.

\begin{tabular}{lccc}
\hline Sample name & $\begin{array}{c}\text { Element } \\
\text { symbol }\end{array}$ & $\begin{array}{c}\text { This study wt\% } \\
\text { dry basis }(\mathrm{db})\end{array}$ & $\begin{array}{c}\text { Ryemsak and Jauro } \\
\text { wt\% dry basis (db) }\end{array}$ \\
\hline Carbon & $\mathrm{C}$ & 75.21 & 82.51 \\
Hydrogen & $\mathrm{H}$ & 6.60 & 4.52 \\
Nitrogen & $\mathrm{N}$ & 1.49 & 1.31 \\
Sulphur & $\mathrm{S}$ & 2.36 & 1.63 \\
Oxygen & $\mathrm{O}$ & 14.36 & 10.03 \\
Atomic hydrogen-carbon ratio & $\mathrm{H} / \mathrm{C}$ & 0.09 & 0.05 \\
Atomic oxygen-carbon ratio & $\mathrm{O} / \mathrm{C}$ & 0.19 & 0.12 \\
Higher heating value $\left(\mathrm{MJ} \mathrm{kg}^{-1}\right)$ & $\mathrm{HHV}$ & 27.37 & 27.22 \\
Moisture & $\mathrm{M}$ & 5.05 & 1.33 \\
Volatiles & $\mathrm{VM}$ & 43.34 & 30.09 \\
Ash & $\mathrm{A}$ & 16.15 & 17.37 \\
Fixed carbon & $\mathrm{FC}$ & 40.50 & 52.26 \\
\hline
\end{tabular}

As can be observed in Table 1, the results of SKJ do not contrast markedly from the reported values in literature. However, the observed difference in elemental composition is due to other researchers employing Seyler's formula ${ }^{21}$ as opposed to using a more precise elemental analyser. The results also demonstrate that SKJ coal contains sufficient constituent elements for thermochemical conversion.

The fixed carbon content is used in conjunction with the calorific: value when assigning a coal ranking. ${ }^{22}$ The high percentage of fixed carbon, $40.50 \%$, may place the coal in the high volatile bituminous B rank, with high potential for coke formation. However, the high compositions of $N, S$, and $A$ potentially present challenges due to the likelihood of producing NOx and SOx gaseous emissions, as well as the possibility of undergoing agglomeration during conversion. Consequently, power generation from SKJ may require clean coal technologies (CCT) integrated with carbon capture and storage (CCS). 
The higher heating value (HHV) is the most important property for the classification (rank) and assessment of the potential of coals. ${ }^{21}$ The HHV for SKJ coal is $27.37 \mathrm{MJ} \mathrm{kg}^{-1}$, which is slightly higher than the value of $27.22 \mathrm{MJ} \mathrm{kg}^{-1}$ that has been reported in literature $\mathrm{e}^{3,23}$ but lower than other Nigerian coals such as Lafia-Obi (30.30 MJ kg ${ }^{-1}$, Enugu (32.90 MJ kg${ }^{-1}$ ) and Okaba $\left(29.70 \mathrm{MJ} \mathrm{kg}^{-1}\right){ }^{24}$ In addition, based on $\mathrm{HHV}$ and $\mathrm{VM},{ }^{21} \mathrm{SKJ}$ can be classified as high-volatile $\mathrm{B}$ bituminous agglomerating coal.

\subsection{Thermogravimetric (TG) Analysis}

Figure 1 presents the burning profile (oxidative thermal) of SKJ coal at different heating rates. The burning profile of coal is vital in assessing its reactivity, combustibility and suitability for combustion systems. ${ }^{25}$ The plots clearly displayed the reverse $S$ - weight loss curves typically observed for thermally decomposing carbonaceous materials under non-isothermal conditions. ${ }^{26,27}$

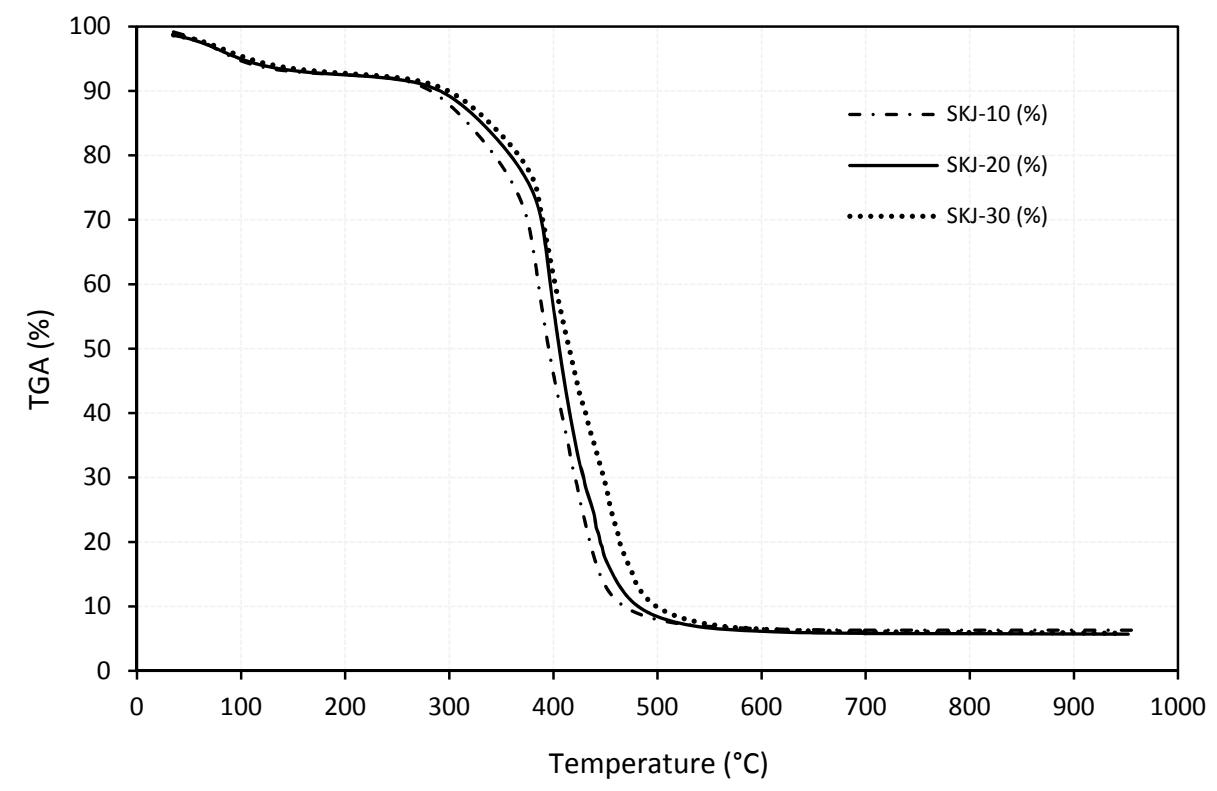

Figure 1: TG plots for SKJ Coal at different heating rates.

The TG plots observably shifted to the right hand side (higher temperatures) due to the thermal-time lag which occurs during TGA at different heating rates. Consequently, the heat transfer and reaction time is limited at higher heating rates, causing the shift in TG curve and temperature profiles. ${ }^{28}$ Hence, the results demonstrate that the change in heating rate influenced the weight loss of SKJ during oxidative conditions. 
The DTG plots for SKJ combustion in Figure 2 revealed the typical endothermic peaks for the derivative weight loss of decomposing materials during TGA. ${ }^{26,27}$

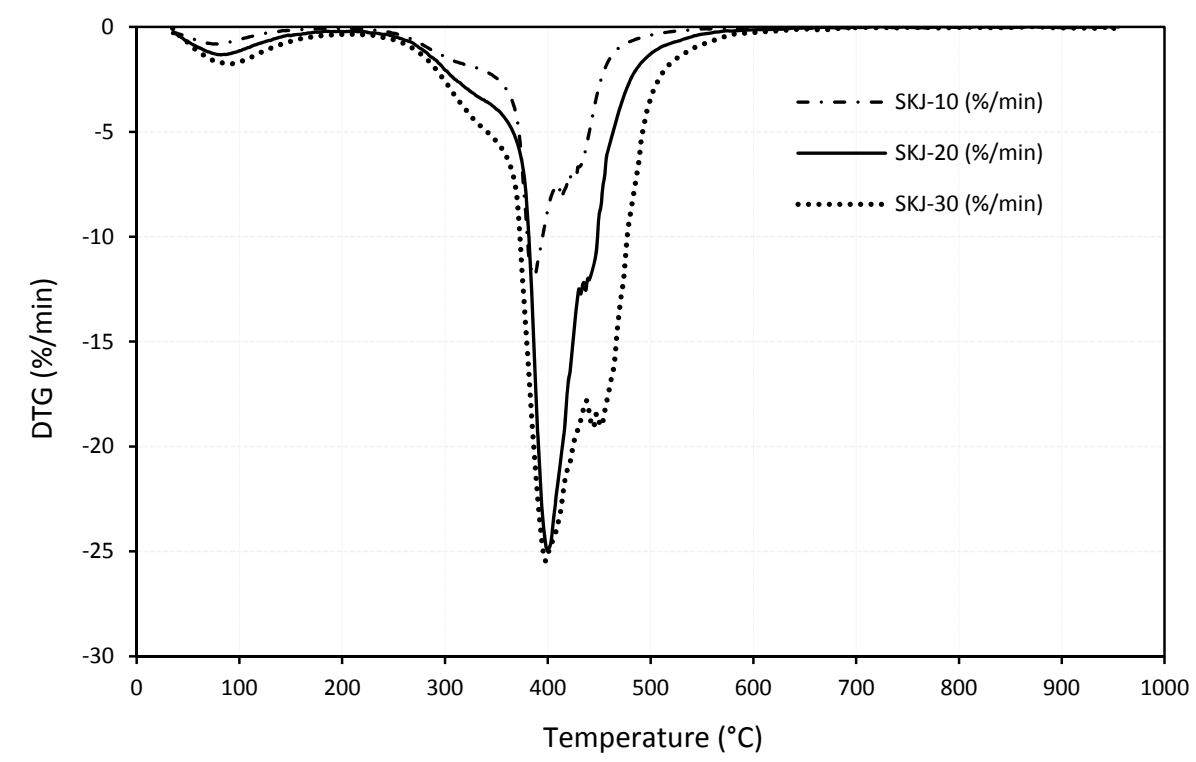

Figure 2: DTG plots for SKJ coal at different heating rates.

Similarly, the effect of heating rate was also observed in the DTG plots for SKJ coal. This indicates that the varying heating rate resulted in an increase in the size and orientation of the DTG plots, which highlights the influence of temperature on SKJ coal degradation. Furthermore, the plots also revealed two endothermic peaks for the degradation of SKJ at 10 and $20^{\circ} \mathrm{C} \mathrm{min}^{-1}$ as was also reported for other Nigerian coals. ${ }^{25}$ However, the DTG plot at $30^{\circ} \mathrm{C} \mathrm{min}^{-1}$ indicated two major peaks and one minor peak, which may indicate a higher rate of reactivity of SKJ.

The weight loss peaks for SKJ coal from $30^{\circ} \mathrm{C}-200^{\circ} \mathrm{C}$ can be ascribed to drying (loss of moisture and mineral hydrates) during thermal degradation. ${ }^{29}$ The weight loss observed during the drying of SKJ coal ranged from $5.95 \%-6.65 \%$, which is in good agreement with the determined moisture content (5.05\%) for SKJ coal presented in Table 1. Moisture can significantly influence coal classification, processing and thermal efficiency during conversion. ${ }^{21}$

The weight loss observed for SKJ from $200^{\circ} \mathrm{C}-600^{\circ} \mathrm{C}$ can be attributed to the devolatilisation of organic matter. The weight loss observed during this stage ranged from $85.95 \%-86.34 \%$, which suggests that weight loss may not be due only to devolatilisation (as the loss of volatile matter, VM, was only $43.34 \%$ ) but also to the presence of other components in the coal composition. 
The combustibility of SKJ was evaluated from the peak decomposition temperature, $T_{\max }$, of the DTG plots. The $T_{\max }$ is the temperature at which maximum weight loss occurs and denotes the ease of ignition, reactivity and coal rank; a lower $T_{\max }$ indicates a higher rank and thus greater ease of burning or coal degradation. ${ }^{25,29,30}$ The $T_{\max }$ for SKJ ranged from $387^{\circ} \mathrm{C}-400^{\circ} \mathrm{C}$ from $10^{\circ} \mathrm{C}-30^{\circ} \mathrm{C}$ $\mathrm{min}^{-1}$, which is similar to values of $384-451^{\circ} \mathrm{C}$ reported for Indonesian coals. ${ }^{31}$ However, Sonibare and co-workers reported $\mathrm{T}_{\max }$ values of $445^{\circ} \mathrm{C}-500^{\circ} \mathrm{C}$ for lignite and sub-bituminous Nigerian coals, ${ }^{25}$ which confirms the higher bituminous rank of SKJ.

\subsection{Combustion Kinetic Analysis}

The FWO model was used to determine the activation energy, $E_{a}$, and frequency factor, $A$, of SKJ coal combustion. The $E_{a}$ and $A$ were obtained from the slope and intercept of the plot of $\operatorname{In}(\beta)$ against $(1 / \mathrm{T})$ at multiple heating rates. Figure 3 presents the kinetic plots for SKJ combustion for conversions $\alpha=0.05-0.90$.

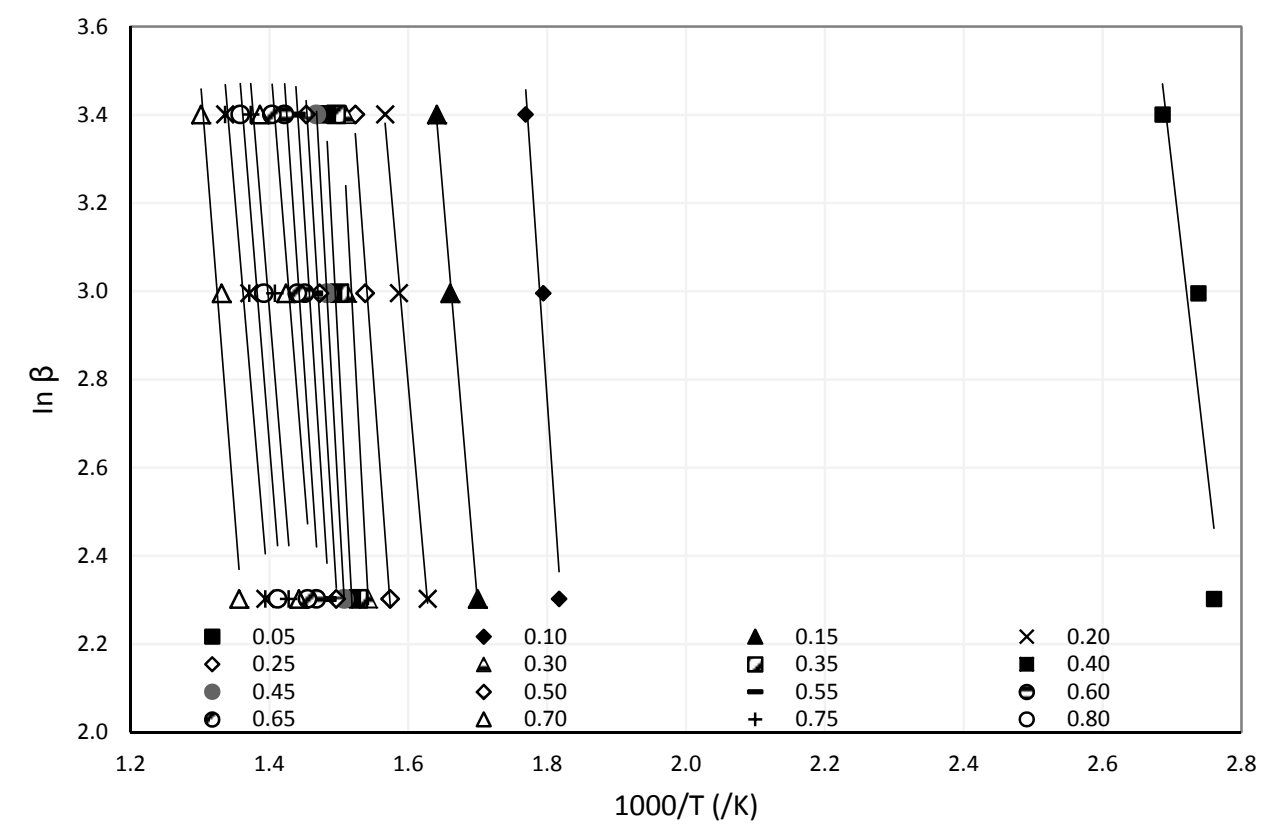

Figure 3: Kinetic plots for SKJ coal combustion.

The values for $E_{a}$ and $A$ for SKJ coal conversion are presented in Table 2. The $E_{a}$ values ranged from $113.13-259.12 \mathrm{~kJ} \mathrm{~mol}^{-1}$, while $A$ ranged from $2.89 \times 10^{13}$ to $1.49 \times 10^{23} \mathrm{~min}^{-1}$ with correlation values of $R^{2}=0.8536-0.9997$. 
Table 2: Kinetic parameters for SKJ coal combustion using FWO method.

\begin{tabular}{ccccccc}
\hline (a) & $\mathrm{R}^{2}$ & $\begin{array}{c}E_{a} \\
\left(\mathrm{~kJ} \mathrm{~mol}^{-1}\right)\end{array}$ & $\begin{array}{c}\text { Frequency } \\
\text { Factor, A } \\
\left(\mathrm{min}^{-1}\right)\end{array}$ & $\begin{array}{c}\mathrm{A} 10^{\circ} \mathrm{C} \mathrm{min}^{-1} \\
\left(\mathrm{~min}^{-1}\right)\end{array}$ & $\begin{array}{c}\mathrm{A} 20^{\circ} \mathrm{C} \mathrm{min}^{-1} \\
\left(\mathrm{~min}^{-1}\right)\end{array}$ & $\begin{array}{c}\mathrm{A} 30^{\circ} \mathrm{C} \mathrm{min}^{-1} \\
\left(\mathrm{~min}^{-1}\right)\end{array}$ \\
\hline 0.05 & 0.8660 & 113.13 & $3.28 \times 10^{18}$ & $3.28 \times 10^{19}$ & $6.55 \times 10^{19}$ & $9.83 \times 10^{19}$ \\
0.10 & 0.9667 & 188.36 & $1.83 \times 10^{20}$ & $1.83 \times 10^{21}$ & $3.67 \times 10^{21}$ & $5.50 \times 10^{21}$ \\
0.15 & 0.9978 & 154.52 & $9.68 \times 10^{15}$ & $9.68 \times 10^{16}$ & $1.94 \times 10^{17}$ & $2.90 \times 10^{17}$ \\
0.20 & 0.9977 & 147.86 & $6.59 \times 10^{14}$ & $6.59 \times 10^{15}$ & $1.32 \times 10^{16}$ & $1.98 \times 10^{16}$ \\
0.25 & 0.9904 & 177.01 & $7.52 \times 10^{16}$ & $7.52 \times 10^{17}$ & $1.50 \times 10^{18}$ & $2.25 \times 10^{18}$ \\
0.30 & 0.9076 & 242.15 & $9.34 \times 10^{21}$ & $9.34 \times 10^{22}$ & $1.87 \times 10^{23}$ & $2.80 \times 10^{23}$ \\
0.35 & 0.9428 & 259.12 & $1.49 \times 10^{23}$ & $1.49 \times 10^{24}$ & $2.98 \times 10^{24}$ & $4.47 \times 10^{24}$ \\
0.40 & 0.9823 & 243.98 & $6.60 \times 10^{21}$ & $6.60 \times 10^{22}$ & $1.32 \times 10^{23}$ & $1.98 \times 10^{23}$ \\
0.45 & 0.9997 & 229.96 & $3.58 \times 10^{20}$ & $3.58 \times 10^{21}$ & $7.16 \times 10^{21}$ & $1.07 \times 10^{22}$ \\
0.50 & 0.9926 & 211.33 & $8.60 \times 10^{18}$ & $8.60 \times 10^{19}$ & $1.72 \times 10^{20}$ & $2.58 \times 10^{20}$ \\
0.55 & 0.9499 & 200.52 & $8.94 \times 10^{17}$ & $8.94 \times 10^{18}$ & $1.79 \times 10^{19}$ & $2.68 \times 10^{19}$ \\
0.60 & 0.9128 & 190.14 & $9.76 \times 10^{16}$ & $9.76 \times 10^{17}$ & $1.95 \times 10^{18}$ & $2.93 \times 10^{18}$ \\
0.65 & 0.8536 & 162.30 & $5.01 \times 10^{14}$ & $5.01 \times 10^{15}$ & $1.00 \times 10^{16}$ & $1.50 \times 10^{16}$ \\
0.70 & 0.8855 & 152.35 & $6.36 \times 10^{13}$ & $6.36 \times 10^{14}$ & $1.27 \times 10^{15}$ & $1.91 \times 10^{15}$ \\
0.75 & 0.9099 & 158.64 & $1.47 \times 10^{14}$ & $1.47 \times 10^{15}$ & $2.93 \times 10^{15}$ & $4.40 \times 10^{15}$ \\
0.80 & 0.9099 & 162.21 & $2.02 \times 10^{14}$ & $2.02 \times 10^{15}$ & $4.04 \times 10^{15}$ & $6.06 \times 10^{15}$ \\
0.85 & 0.9291 & 153.11 & $2.89 \times 10^{13}$ & $2.89 \times 10^{14}$ & $5.77 \times 10^{14}$ & $8.66 \times 10^{14}$ \\
0.90 & 0.9623 & 165.46 & $1.12 \times 10^{14}$ & $1.12 \times 10^{15}$ & $2.25 \times 10^{15}$ & $3.37 \times 10^{15}$ \\
\hline & 0.9420 & 184.01 & $9.19 \times 10^{21}$ & $9.19 \times 10^{22}$ & $1.84 \times 10^{23}$ & $2.76 \times 10^{23}$ \\
\hline & & & & & & \\
\hline
\end{tabular}

The average $E_{a}, A$ and $R^{2}$ values were $184.01 \mathrm{~kJ} \mathrm{~mol}^{-1}, 9.19 \times 10^{23} \mathrm{~min}^{-1}$ and 0.9420 , respectively. These $E_{a}$ and $A$ values are significantly higher than those reported for the combustion of other Nigerian coals. ${ }^{25}$ Sonibare and co-workers reported $\mathrm{E}_{\mathrm{a}}$ values in the range of $68-90 \mathrm{~kJ} \mathrm{~mol}^{-1}$ and $A$ values between $1.1 \times$ $10^{1}-6.7 \times 10^{2} \mathrm{~min}^{-1}$ for lignite and sub-bituminous coals. ${ }^{25}$ Evidently, this difference is due to the coal rank and reactivity, which differs when compared to the bituminous SKJ coal examined in this study.

\section{CONCLUSION}

The study presented the physicochemical and thermokinetic decomposition properties of the newly discovered Shankodi-Jangwa (SKJ) coal. The results indicate that SKJ contains high contents of fixed carbon, volatile matter and sulphur. Based on its heating value and volatile matter, SKJ was classified as 
high-volatile B bituminous agglomerating coal. Thermal analysis revealed the high reactivity, combustibility and thermally degradability of SKJ below $1000^{\circ} \mathrm{C}$. The average decomposition was $94.05 \%$ for multi-heating rate combustion from $35^{\circ} \mathrm{C}-1000^{\circ} \mathrm{C}$. The activation energy, $E_{a}$ and frequency factor, $A$, were determined using FWO model kinetics. The average values of $E a, A$ and $\mathrm{R}^{2}$ were $184.01 \mathrm{~kJ} \mathrm{~mol}^{-1}, 9.19 \times 10^{23} \mathrm{~min}^{-1}$ and 0.9420 , respectively. The results presented will be vital in the modelling and design of future combustion systems for SKJ coal.

\section{ACKNOWLEDGMENT}

The authors acknowledge the financial support of Universiti Teknologi Malaysia (UTM), VOT No. 07H12 and material support from National Centre for Petroleum Research and Development (NCPRD), Bauchi, Nigeria. The kind assistance of Dr Y. A. Dodo, Dr S. L. Wong, Arc A. S. El-Nafaty, and Pn. Zainab are gratefully acknowledged.

\section{REFERENCES}

1. IEA-OECD. (2013). World energy outlook. OECD working paper, London, 12 November.

2. Yandoka, B. M. S. et al. (2015). Geochemistry of the Cretaceous coals from Lamja Formation, Yola Sub-basin, Northern Benue Trough, NE Nigeria: Implications for paleoenvironment, paleoclimate and tectonic setting. J. Afr. Earth Sci., 104, 56-70, http://dx.doi.org/10.1016/ j.jafrearsci.2015.01.002.

3. Ryemshak, S. A. \& Jauro, A. (2013). Proximate analysis, rheological properties and technological applications of some Nigerian coals. Int. $J$. Ind. Chem., 4(1), 1-7.

4. Equatorial Mining \& Exploration. 2015. Projects and operations: Afuze coalfields. Retrieved 1 June 2015 from http://www.equatorialmining. com/projects-operations/afuze-coalfields.

5. Onwu, D., Inyiama, F. \& Ejikeme, P. (2007). Rheology of Coal-water fuel from Enugu coal. J. Eng. Appl. Sci., 3, 1-7.

6. Wuyep, E. O. \& Obaje. N. G. (2012). Petrographic evaluation of the ranks and technological applications of some coal deposits in the Anambra Basin and Middle Benue Trough of Nigeria. J. Earth Sci. Eng., 2(4), 220-234.

7. Bassey, C. \& Eminue, O. (2012). Petrographic and stratigraphic analyses of Palaeogene Ogwashi-Asaba formation, Anambra Basin, Nigeria. Nafta, 63(7-8), 247-254. 
8. Odeh, A. O. (2015). Exploring the potential of petrographics in understanding coal pyrolysis. Energy, 87, 555-565.

9. Olajire, A. et al. (2007). Occurrence and distribution of metals and porphyrins in Nigerian coal minerals. J. Fuel Chem. Technol., 35(6), 641-647.

10. Ogala, J., Siavalas, G. \& Christanis, K. (2012). Coal petrography, mineralogy and geochemistry of lignite samples from the Ogwashi-Asaba Formation, Nigeria. J. Afr. Earth Sci., 66, 35-45, http://dx.doi.org/ 10.1016/j.jafrearsci.2012.03.003.

11. Jauro, A. et al. (2007). Organic geochemistry of Cretaceous Lamza and Chikila coals, upper Benue trough, Nigeria. Fuel, 86(4), 520-532, http://dx.doi.org/10.1016/j.fuel.2006.07.031.

12. Ogala, J. E. (2012). The geochemistry of lignite from the neogene ogwashi-asaba formation, niger delta basin, southern nigeria. Earth Sci. Res. J., 16(2), 151-164.

13. Adegoke, A. K., Abdullah, W. H. \& Hakimi, M. H. (2015). Geochemical and petrographic characterisation of organic matter from the Upper Cretaceous Fika shale succession in the Chad (Bornu) Basin, northeastern Nigeria: Origin and hydrocarbon generation potential. Mar. Pet. Geol., 61, 95-110, http://dx.doi.org/10.1016/j.marpetgeo.2014.12.008.

14. Popoola, O. T. \& Asere, A. A. (2013). Emission and combustion characteristics of Lafia-Obi Coal in fluidized bed combustor. Adv. Mater. Res., 824, 318-326, http://dx.doi.org/10.4028/www.scientific.net/AMR. 824.318.

15. Amoo, L. M. (2015). Computational fluid dynamics simulation of LafiaObi bituminous coal in a fluidized-bed chamber for air- and oxy-fuel combustion technologies. Fuel, 140, 178-191, http://dx.doi.org/10. 1016/j.fuel.2014.09.076.

16. Jauro, A. et al. (2014). Hydrocarbon generating potentials of Benue Trough Coals. In Bhowon, M. G. et al (Eds), Chemistry: The key to our sustainable future, 75-91. Dordrecht: Springer.

17. Adedosu, T. et al. (2010). Hydrocarbon-generative potential of coal and interbedded shale of Mamu formation, Benue Trough, Nigeria. Pet. Sci. Technol., 28(4), 412-427, http://dx.doi.org/10.1080/1091646 0902725306.

18. Xiao, H.-m., Ma, X.-q. \& Lai, Z.-y. (2009). Isoconversional kinetic analysis of co-combustion of sewage sludge with straw and coal. Appl. Energy, 86(9), 1741-1745, http://dx.doi.org/10.1016/j.apenergy. 2008.11.016.

19. Chen, C., Ma, X. \& He, Y. (2012). Co-pyrolysis characteristics of microalgae Chlorella vulgaris and coal through TGA. Biores. Technol., 117, 264-273, http://dx.doi.org/10.1016/j.biortech.2012.04.077. 
20. Doyle, C. D. (1965). Series approximations to the equation of thermogravimetric data. Nature, 207(4994), 290-291, http://dx.doi.org/ $10.1038 / 207290 \mathrm{a} 0$.

21. Speight, J. G. (2012). The chemistry and technology of coal. Florida: CRC Press, http://dx.doi.org/10.1002/aic.690310627.

22. Schweinfurth, S. P. (2009). An introduction to coal quality. In Pierce, B. S. and Dennen, K. O. (Eds). The national coal resource assessment overview. U.S. Geological Survey Professional Paper 1625-F, Virginia, USA.

23. Nyakuma, B. B. (2015). Physicochemical characterization of low rank Nigerian coals. Student paper, Universiti Teknologi Malaysia.

24. Ohimain, E. I. (2014). Can Nigeria generate $30 \%$ of her electricity from coal by 2015? Int. J. Energy Power Eng., 3(1), 28-37, http://dx.doi.org/10.11648/j.ijepe.20140301.15.

25. Sonibare, O. et al. (2005). An investigation into the thermal decomposition of Nigerian coal. J. Appl. Sci., 5(1), 104-107, http://dx.doi.org/10.3923/jas.2005.104.107.

26. Nyakuma, B. B. et al. (2015). Non-isothermal kinetic analysis of oil palm empty fruit bunch pellets by thermogravimetric analysis. Chem. Eng. Trans., 45, 1327-1332, http://dx.doi.org/10.3303/CET1545222.

27. Nyakuma, B. B. (2015). Thermogravimetric and kinetic analysis of melon (Citrullus colocynthis L.) seed husk using the distributed activation energy model. Environ. Climate Technol., 15(1), 77-89, http://dx.doi.org/10.1515/rtuect-2015-0007.

28. Slopiecka, K., Bartocci, P. \& Fantozzi, F. (2012). Thermogravimetric analysis and kinetic study of poplar wood pyrolysis. Appl. Energy, 97, 491-497, http://dx.doi.org/10.1016/j.apenergy.2011.12.056.

29. Sarwar, A., Khan, M. N. \& Azhar, K. F. (2014). The physicochemical characterization of a newly explored Thar coal resource. Energy Sources A, 36(5), 525-536, http://dx.doi.org/10.1080/15567036.2010.542447.

30. Goswami, D. Y. 2004. The CRC handbook of mechanical engineering. Florida: CRC Press.

31. Umar, D. F., Usui, H. \& Daulay, B. (2006). Change of combustion characteristics of Indonesian low rank coal due to upgraded brown coal process. Fuel Process. Technol., 87(11), 1007-1011. 